DOI:10.22337/2587-9618-2017-13-4-66-81

ИССЛЕДОВАНИЕ ПОВЕДЕНИЯ ЦЕМЕНТНЫХ КОМПОЗИТОВ В УСЛОВИЯХ ПОВЫШЕННОЙ ВЛАЖНОСТИ И ПЕРЕМЕННЫХ ПОЛОЖИТЕЛЬНЫХ ТЕМПЕРАТУР

\author{
И.В. Ерофеева ${ }^{1}$ В.В. Афонин ${ }^{1}$ В.А. Федорцов ${ }^{1}$, Д.В. Емельянов \\ Н.Н. Поджсивотов ${ }^{2}$ М.М. Зоткина \\ ${ }^{1}$ Мордовский государственный университет им. Н.П. Огарёва, г. Саранск, РОССИЯ \\ ${ }^{2}$ Всероссийский научно-исследовательский институт авиационных материалов ГНЦ РФ, г. Москва, РОССИЯ

\begin{abstract}
Аннотация: В работе приводятся результаты испытаний цементных композитов в условиях воздействия на них повышенной влажности и переменных положительных температур. По коэффициенту изменения твердости (стойкости) сравниваются составы с различными наполнителями, пластифицирующими и другими фунгицидными добавками. Для принятия решения о стойкости (устойчивости) структуры и свойств композитов предлагается опираться на величину площади многоугольника, полученного в результате кусочно-линейной аппроксимации точек экспонирования. Даются объяснения влияния факторов среды на изменение твердости композитов.
\end{abstract}

Ключевые слова: композиты, влажность, положительные температуры, коэффициент стойкости, площадь многоугольника, составы композитных материалов, устойчивость, относительные значения, кусочно-линейная интерполяция

\title{
RESEARCH OF BEHAVIOR OF CEMENT COMPOSITES IN CONDITIONS OF HIGH HUMIDITY AND VARIABLE POSITIVE TEMPERATURES
}

\author{
Irina V. Erofeeva ${ }^{1}$, Victor V. Afonin ${ }^{1}$, Vladislav A. Fedortsov ${ }^{l}$,

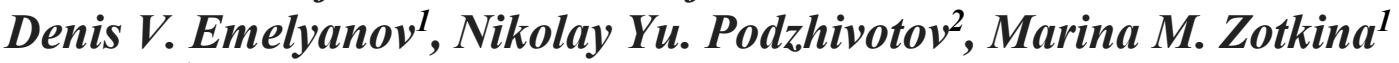 \\ ${ }^{1}$ National Research Ogarev Mordovia State University, Saransk, RUSSIA \\ ${ }^{2}$ All-Russian Scientific Research Institute of Aviation Materials GNC RF, Moscow, RUSSIA
}

\begin{abstract}
In this paper, the results of testing cement composites under the conditions of the effect of high humidity and variable positive temperatures are given. By the coefficient of variation of hardness (stability), the compositions are compared with various fillers, plasticizing and other fungicidal additives. To decide on the stability (stability) of the structure and properties of composites, it is proposed to rely on the area of the polygon obtained as a result of piecewise linear approximation of the exposure points. Explanations of the influence of environmental factors on hardness change of the composites.
\end{abstract}

Keywords: composites, humidity, positive temperatures, coefficient of stability, polygon area, compositions of composite materials, stability, relative values, piecewise linear interpolation

Цементные композиты во время своей эксплуатации могут подвергаться воздействию различных климатических факторов. Основными из них являются влажность и температура окружающей среды. Эти факторы могут действовать в различном сочетании. Есть и такие воздействия, когда можно считать, что один из этих факторов в течение суток остается постоянным, а второй меняется. Очевидно, что в этом случае задача по определению влияния составляющих окружающей 
Исследование поведения цементных композитов в условиях повышенной влажности и переменных положительных температур

среды на изменение механических свойств композитов упрощается.

В данной статье исследуются композиты на цементной основе, выдержанные в условиях повышенной влажности и переменных положительных температур. За основу исследования принято выполненное авторами исследование поведения цементных композтов в условиях циклического воздействия отрицательных и положительных температур.

Одним из важнейших свойств строительных материалов и, в частности, цементных композитов является их способность сопротивляться действию окружающей среды, которая оценивается коэффициентом стойкости (устойчивости) структуры и свойств физическим, химическим и другим воздействиям.

Исследования выполнены в 4 этапа:

- сравнивались результаты по составам цементного камня с различным водосодержанием и с введением гиперпластификатора (этап №1);

- цементным композитам, включающих в своем составе песочные фракции, а также добавки микрокремнезема с каменной мукой (этап №2);

- $\quad$ на активированной воде затворения (этап №3);

- цементные композиты, имеющие в своем составе биоцидные добавки (этап №4).

Для различных композитов, с различными добавками значения коэффициентов стойкости, как правило, заметно различаются. Исследованию стойкости строительных композитов в различных эксплуатационных средах посвящено достаточно много работ, включая работы авторов [1-17]. Коэффициент стойкости устанавливают по характеру изменения физико-механических и других свойств. В наших исследованиях стойкость оценивали по изменению твердости на поверхности образцов. Как известно, твердость напрямую связана с показателем прочности [18]. Контрольные точки времени изменения свойств композитов фиксировались через 15 и 45 суток испытаний. Начальная точка ноль соответствует контрольному показателю свойства.
В качестве объектов исследования рассматривались цементные композиты, составы которых приведены в таблице 1 .

Образцы композитов, приведенных составов, подвергали термоцикли-ческим испытаниям. Один термоцикл длился 24 часа и включал четыре термосостояния:

- нагрев образцов от комнатной температуры $\left(+23{ }^{\circ} \mathrm{C}\right)$ до $+60{ }^{\circ} \mathrm{C}$ при влажности $98 \%$ - около 5 мин.;

- выдержка образцов при температуре $+60{ }^{\circ} \mathrm{C}$ и влажности $98 \%-9$ часов;

- при выключенной камере естественное остывание образцов до комнатной - температуры $\left(+23^{\circ} \mathrm{C}\right)$ при влажности $98 \%$ примерно 5 часов 55 мин.;

- $\quad$ выдержка образцов при комнатной температуре $\left(+23{ }^{\circ} \mathrm{C}\right)$ при влажности $98 \%$ 9 часов.

Таким образом, композиты испытывали при постоянной высокой влажности и переменных положительных температурах.

Для сравнения композитов по коэффициентам стойкости целесообразно их привести к относительным значениям, относительно контрольного образца перед началом экспонирования. Тогда характерный вид зависимостей относительного значения свойства (например, коэффициента твердости) может быть приведена в том виде, как показано на рис. 1.

На рис. 1 под каждой ломаной прямой выделены области в виде многоугольников, для которых можно рассчитать площадь $(\boldsymbol{S})$, например, по методу трапеций. Формально размерность таких площадей соответствует размерности времени. Форма многоугольников может быть разнообразной. По величине площади предлагается оценивать стойкость составов композитов к изменениям свойств их структуры, соответственно и свойств. Контрольный образец композита обозначим как состав 1. Сравниваемые образцы будем обозначать как 2, 3 и т. д. (см. таблицу 1).

Рассмотрим сначала композиты (составы 1,2$)$, основу которых составляет цементный камень. 
Таблица 1. Исследуемые составы иементных композитов и их начальные механические характеристики.

\begin{tabular}{|c|c|c|c|c|}
\hline $\begin{array}{c}\text { № } \\
\text { со- } \\
\text { става }\end{array}$ & $\begin{array}{c}\text { Исходные составляющие вещества } \\
\text { композита }\end{array}$ & $\begin{array}{c}\text { Количество вещества } \\
\text { по отношению } \\
\text { к содержанию } \\
\text { цемента, отн. числа } \\
\end{array}$ & $\begin{array}{l}\text { Прочность } \\
\text { на сжатие, } \\
\text { МПа }\end{array}$ & $\begin{array}{c}\text { Показатель } \\
\text { твердости, МПа }\end{array}$ \\
\hline 1 & $\begin{array}{l}\text { Цемент ульяновский ПЦ500Д0 } \\
\text { Вола }\end{array}$ & $\begin{array}{c}1 \\
0,267 \\
\end{array}$ & 56,4 & 4010,17 \\
\hline 2 & $\begin{array}{l}\text { Цемент ульяновский ПЦ500Д0 } \\
\text { Вода }\end{array}$ & $\begin{array}{c}1 \\
0,35\end{array}$ & 52,6 & 2065,24 \\
\hline 3 & $\begin{array}{l}\text { Цемент ульяновский ПЦ500Д0 } \\
\text { ГП «Melflux 1641 F» } \\
\text { Вода } \\
\end{array}$ & $\begin{array}{c}1 \\
0,009 \\
0,171 \\
\end{array}$ & 133 & 7016,08 \\
\hline 4 & $\begin{array}{l}\text { Цемент ульяновский ПЦ500Д0 } \\
\text { Песок молотый (микрокварц) } \\
\text { Песок фр. 0-0.63 мм (г. Иваново) } \\
\text { Песок фр. 0,63-2,5 мм (г. Иваново) } \\
\text { ГП «Melflux 1641 F» } \\
\text { Вода }\end{array}$ & $\begin{array}{c}1 \\
1,1 \\
2,753 \\
2,347 \\
0,009 \\
0,6\end{array}$ & 67,1 & 5476,90 \\
\hline 5 & $\begin{array}{l}\text { Цемент ульяновский ПЦ500Д0 } \\
\text { Песок молотый (микрокварц) } \\
\text { Микрокремнезем } \\
\text { Песок фр. 0-0.63 мм (г. Иваново) } \\
\text { Песок фр. 0,63-2,5 мм (г. Иваново) } \\
\text { ГП «Melflux 1641 F» } \\
\text { Вода }\end{array}$ & $\begin{array}{c}1 \\
0,75 \\
0,1 \\
1,775 \\
1,975 \\
0,009 \\
0,475\end{array}$ & 110 & 9746,86 \\
\hline 6 & $\begin{array}{l}\text { Цемент ульяновский ПЦ500Д0 } \\
\text { Песок фр. 0-0.63 мм (г. Иваново) } \\
\text { Песок фp. 0,63-2,5 мм (г. Иваново) } \\
\text { ГП «Melflux 1641 F» } \\
\text { Вода }\end{array}$ & $\begin{array}{c}1 \\
2,065 \\
1,76 \\
0,009 \\
0,525 \\
\end{array}$ & 32,5 & 4089,57 \\
\hline 7 & $\begin{array}{l}\text { Цемент ульяновский ПЦ500Д0 } \\
\text { Песок фр. 0-0.63 мм (г. Иваново) } \\
\text { Песок фр. 0,63-2,5 мм (г. Иваново) } \\
\text { ГП «Melflux 1641 F» } \\
\text { Вода }\end{array}$ & $\begin{array}{c}1 \\
2,51 \\
2,14 \\
0,009 \\
0,56\end{array}$ & 41 & 1187,85 \\
\hline 8 & $\begin{array}{l}\text { Цемент ульяновский ПЦ500Д0 } \\
\text { Песок молотый (микрокварц) } \\
\text { Песок фр. 0-0.63 мм (г. Иваново) } \\
\text { Песок фр. 0,63-2,5 мм (г. Иваново) } \\
\text { ГП «Хидетал 9ү» } \\
\text { Вода }\end{array}$ & $\begin{array}{c}1 \\
0,825 \\
2,065 \\
1,76 \\
0,012 \\
0,56\end{array}$ & 55 & 7488,59 \\
\hline M3 & $\begin{array}{l}\text { Цемент ульяновский ПЦ500Д0 } \\
\text { Вода активированная по режиму } \\
\text { Э+М (3-3) }\end{array}$ & $\begin{array}{c}1 \\
0,26\end{array}$ & 85 & 5168,04 \\
\hline T3 & $\begin{array}{l}\text { Цемент ульяновский ПЦ500Д0 } \\
\text { Биоцидная добавка } \\
\text { «Теfleх Универсальный» } \\
\text { Вода }\end{array}$ & $\begin{array}{c}1 \\
0,03 \\
0,267\end{array}$ & 32 & 1174,46 \\
\hline
\end{tabular}


Исследование поведения цементных композитов в условиях повышенной влажности и переменных положительных температур

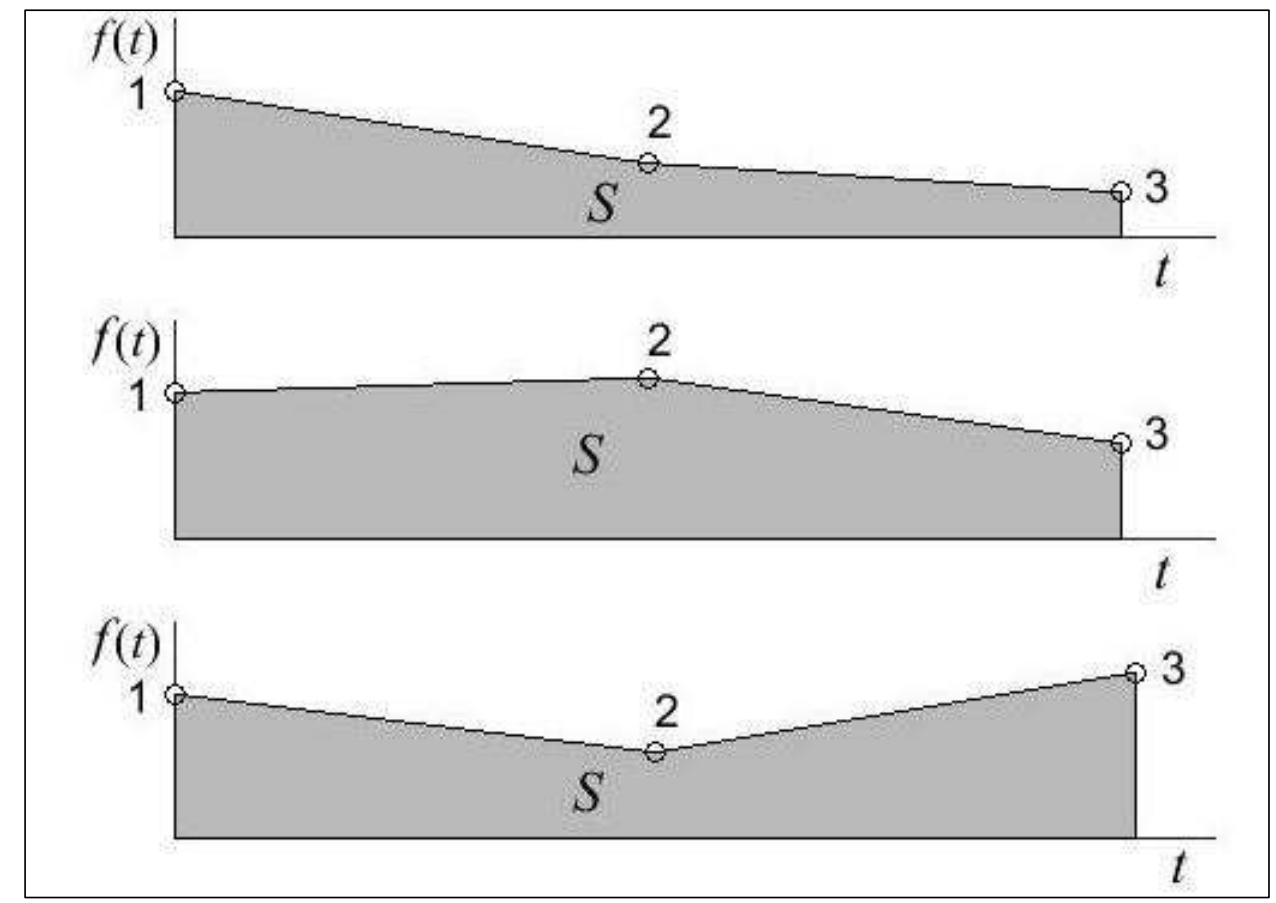

Рисунок 1. Примеры изменения относительного показателя свойства и ограниченной им площзади многоугольника

Таблица 2. Результаты экспонирования композитов при повышенной влажности и переменной положительной температуре $\left(22-60^{\circ} \mathrm{C}\right)$ составов 1,2

\begin{tabular}{|c|c|c|c|c|c|c|}
\hline $\begin{array}{c}\text { Длительность } \\
\text { экспонирования, } \\
\text { сутки }\end{array}$ & \multicolumn{2}{|c|}{$\begin{array}{c}\text { Показатели } \\
\text { твердости, } \\
\text { МПа, для составов }\end{array}$} & \multicolumn{2}{|c|}{$\begin{array}{c}\text { Относительные } \\
\text { показатели } \\
\text { твердости } \\
\text { для составов }\end{array}$} & \multicolumn{2}{|c|}{$\begin{array}{c}\text { Площадь } \\
\text { многоугольника, } \\
\text { для составов }\end{array}$} \\
\cline { 1 - 5 } & 1 & 2 & 1 & 2 & 1 & 2 \\
\hline 0 & 4010,17 & 2065,24 & 1,00000 & 1,00000 & 46,85506 & 69.92950 \\
\hline 15 & 4308,81 & 3492,44 & 1,07447 & 1,69106 & & \\
\hline 45 & 4058,15 & 3356,80 & 1,01196 & 1,62538 & & \\
\hline
\end{tabular}

Изменение показателей твердости композитов по мере выдержки в среде, а также значения площадей многоугольников, рассчитанных по рис. 2 приведены в табл. 2. Видно, что для композита состава 2, имеющего по мере испытания повышение показателей твердости по сравнению с материалом состава 1 , имеет место и значительное превышение площади многоугольника.

Из табл. 2 и рис. 2 следует, что по показателю твердости состав на основе теста нормальной густоты является более прочным, нежели состав с повышенным водосодержанием. В тоже время при воздействии среды у состава с повышенным водосодержанием произошло увеличение рассматриваемого показателя. Это, по-видимому, объясняется в большей степени, чем для материала состава 1 , снижением поверхностной пористости образцов изза общей тенденции уменьшения их поверхности за счет продолжения гидратации вяжущего, поверхностной карбонизации цементного камня и других процессов, способствующих уменьшению поверхностной энергии.

Рассмотрим составы 1 и 3 . Состав 3 относится к цементному камню из самоуплотняющейся цементной суспензии с гиперпластификатором. 
И.В. Ерофеева, В.В. Афонин, В.А. Федорцов, Д.В. Емельянов, Н.В. Подживотов, М.М. Зоткина

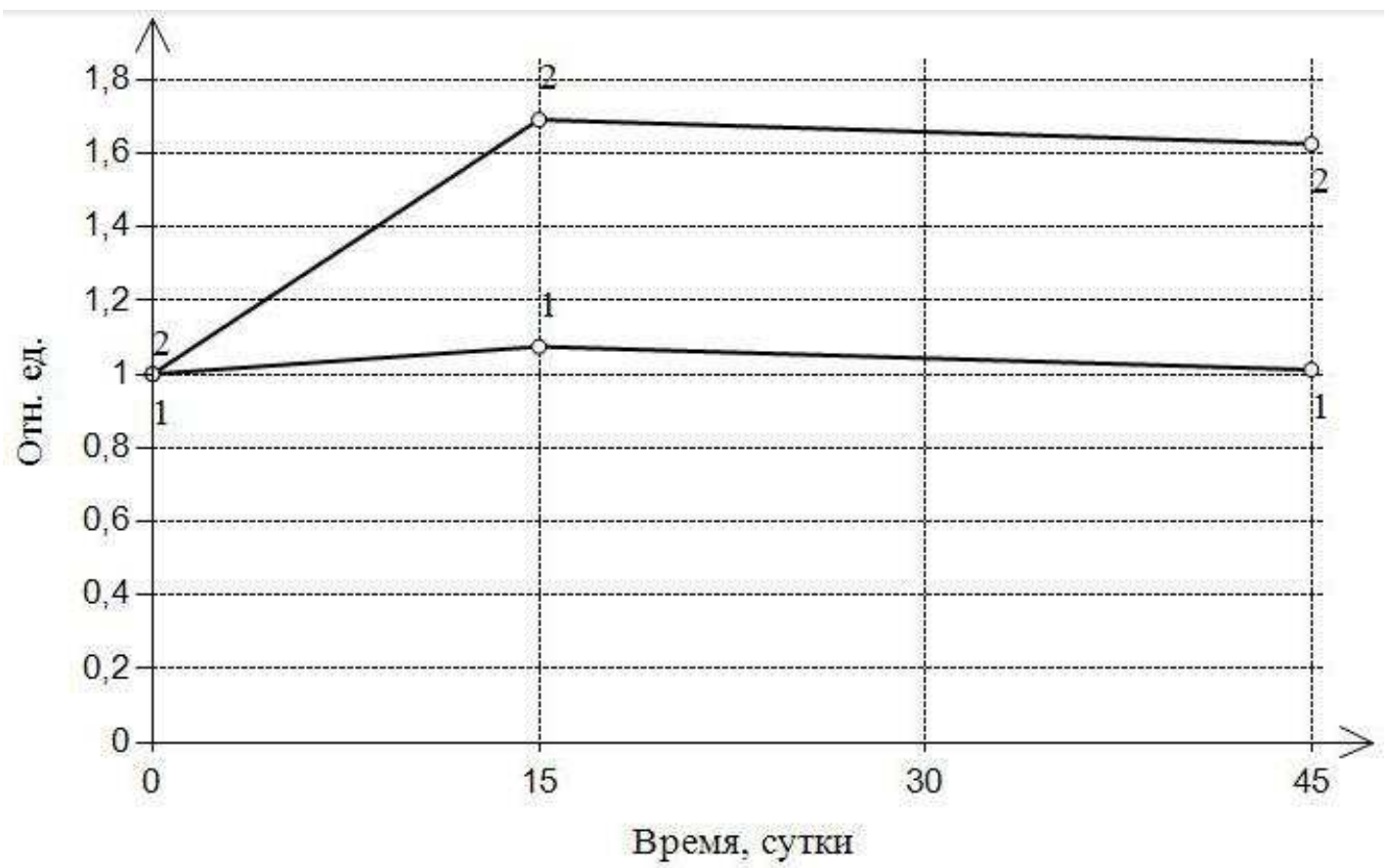

Рисунок 2. Изменение коэффициента твердости композита в зависимости от времени воздействия среды для составов 1 и 2

Таблица 3. Результаты экспонирования композитов при повышенной влажности и переменной положительной температуре $\left(22-60^{\circ} \mathrm{C}\right)$ составов 1,3

\begin{tabular}{|c|c|c|c|c|c|c|}
\hline $\begin{array}{c}\text { Длительность } \\
\text { экспонирования, } \\
\text { сутки }\end{array}$ & \multicolumn{2}{|c|}{$\begin{array}{c}\text { Показатели } \\
\text { твердости МПа, } \\
\text { для составов }\end{array}$} & \multicolumn{2}{|c|}{$\begin{array}{c}\text { Относительные } \\
\text { показатели }\end{array}$} & \multicolumn{2}{|c|}{$\begin{array}{c}\text { Площадь } \\
\text { многоугольника, } \\
\text { для составов }\end{array}$} \\
\cline { 2 - 5 } & 1 & 3 & 1 & 3 & 1 & 3 \\
\hline 0 & 4010,17 & 7016,08 & 1,00000 & 1,00000 & 46,85506 & 37,38871 \\
\hline 15 & 4308,81 & 4926,15 & 1,07447 & 0,70212 & & \\
\hline 45 & 4058,15 & 6590,88 & 1,01196 & 0,93940 & & \\
\hline
\end{tabular}

Результаты расчетов, аналогичные, отраженным в таблице 2, приведены в таблице 3. Диаграмма с изменениями коэффициентов твердости от времени для композитов составов 1 и 3 показаны на рис. 3.

Сравнение результатов испытаний по абсолютным показателям свидетельствует о более высокой прочности составов с добавками гиперпластификатора. В тоже время следует отметить сохранение поверхностной твердости у композита на основе теста нормальной густоты без пластифицирующих доба- вок (рис. 3). Как в предыдущем случае повышение и сохранение твердости более выражено у менее твердого (прочного) композита, а соответственно более пористого. У изначально более твердого материала в начальное время выдержки происходит уменьшение твердости с последующим ее возрастанием.

Рассмотрим составы 1, 3 и 6. Состав 6 относится к песчаному бетону переходного поколения с ГП. Результаты расчетов приведены в табл. 4. Диаграмма с изменениями коэффициентов твердости от времени для составов 1, 3 и 6 приведены на рис. 4. 
Исследование поведения цементных композитов в условиях повышенной влажности и переменных положительных температур

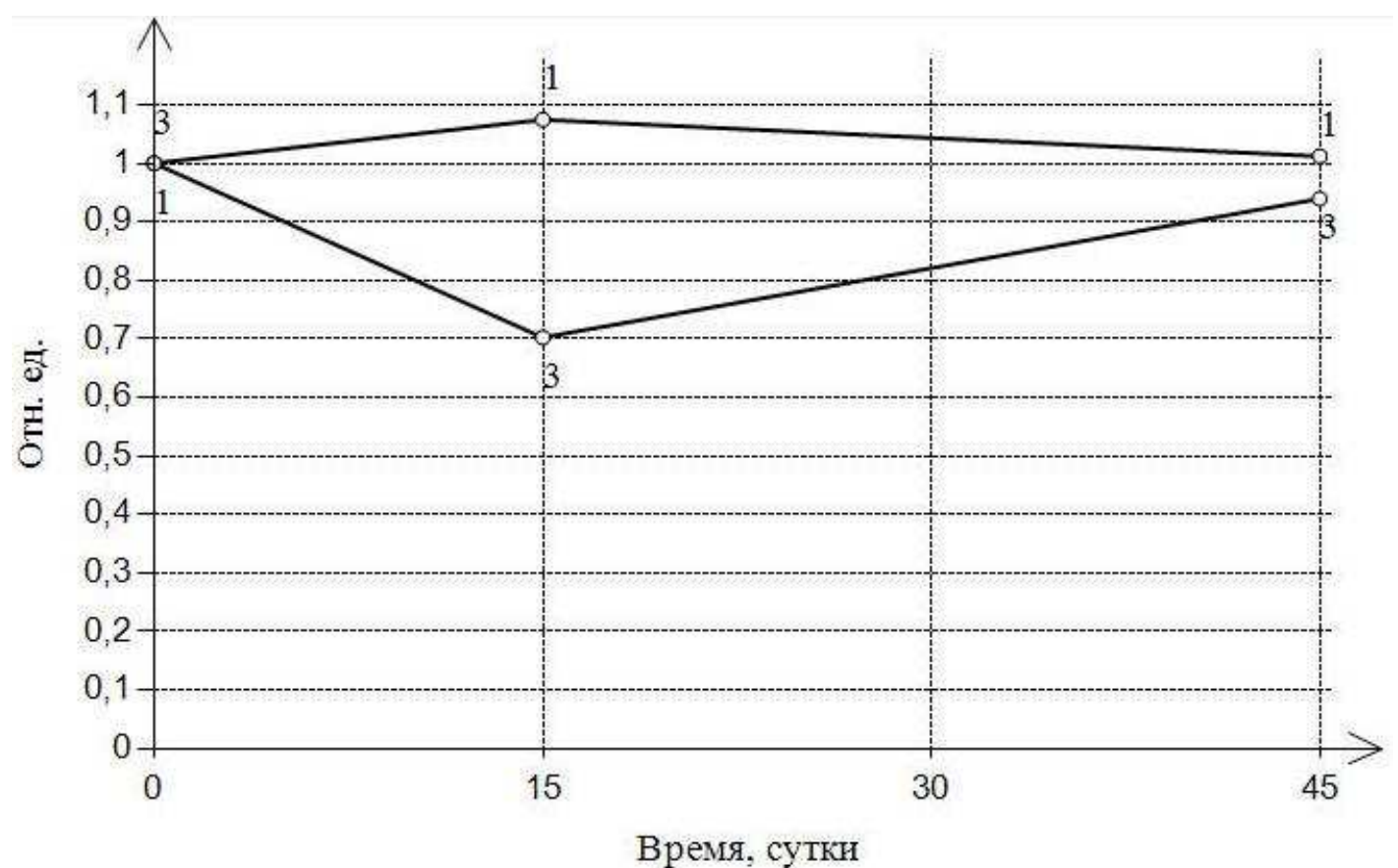

Рисунок 3. Изменение коэффициента твердости композита в зависимости от времени воздействия среды для составов 1 и 3.

Таблича 4. Результаты экспонирования композитов при повыпенной влажности и переменной положительной температуре $\left(22-60^{\circ} \mathrm{C}\right)$ составов 1, 3, 6.

\begin{tabular}{|c|c|c|c|c|c|c|c|c|c|}
\hline $\begin{array}{l}\text { Длитель- } \\
\text { ность } \\
\text { экспони- } \\
\text { рования, }\end{array}$ & \multicolumn{3}{|c|}{$\begin{array}{c}\text { Показатели } \\
\text { твердости МПа, } \\
\text { для составов }\end{array}$} & \multicolumn{3}{|c|}{$\begin{array}{c}\text { Относительные } \\
\text { показатели твердости } \\
\text { для составов }\end{array}$} & \multicolumn{3}{|c|}{$\begin{array}{c}\text { Площадь } \\
\text { многоуголь- } \\
\text { ника, } \\
\text { для составов }\end{array}$} \\
\hline сутки & 1 & 3 & 6 & 1 & 3 & 6 & 1 & 3 & 6 \\
\hline 0 & 4010,17 & 7016,08 & 4089,57 & 1,00000 & 1,00000 & 1,00000 & \multirow{3}{*}{$\begin{array}{l}8 \\
\circ \\
n \\
\infty \\
\infty \\
0 \\
+\end{array}$} & \multirow{3}{*}{$\begin{array}{l}\vec{N} \\
\infty \\
\infty \\
n \\
n\end{array}$} & \multirow{3}{*}{$\begin{array}{l}\infty \\
\stackrel{\infty}{1} \\
\tilde{8}\end{array}$} \\
\hline 15 & 4308,81 & 4926,15 & 5337,79 & 1,07447 & 0,70212 & 1,30522 & & & \\
\hline 45 & 4058,15 & 6590,88 & 6342,20 & 1,01196 & 0,93940 & 1,55082 & & & \\
\hline
\end{tabular}

Результаты испытаний, рассмотренных материалов, приведенные в таблице 4 и графиках изменения коэффициентов твердости (рис. 4), подтверждают ранее полученные показатели, что увеличение воздействия повышенной влажностью и переменными положительными температурами в пределах $22-60{ }^{\circ} \mathrm{C}$ приводит к снижению пористости материалов и тем самым увеличению показателя твердости.
Рассмотрим составы 1, 4, 5, 6. Состав №4 - это песчаный бетон нового поколения с ГП и каменной муки (КМ), а состав 5 - это песчаный бетон нового поколения с МК (с использованием микрокремнезема) и ГП (с гиперпластификатором). Диаграмма с изменениями коэффициентов твердости от времени выдержки для композитов составов 1, 4, 5, 6 приведены на рис. 5, а результаты расчетов приведены в таблице 5. 
И.В. Ерофеева, В.В. Афонин, В.А. Федорцов, Д.В. Емельянов, Н.В. Подживотов, М.М. Зоткина

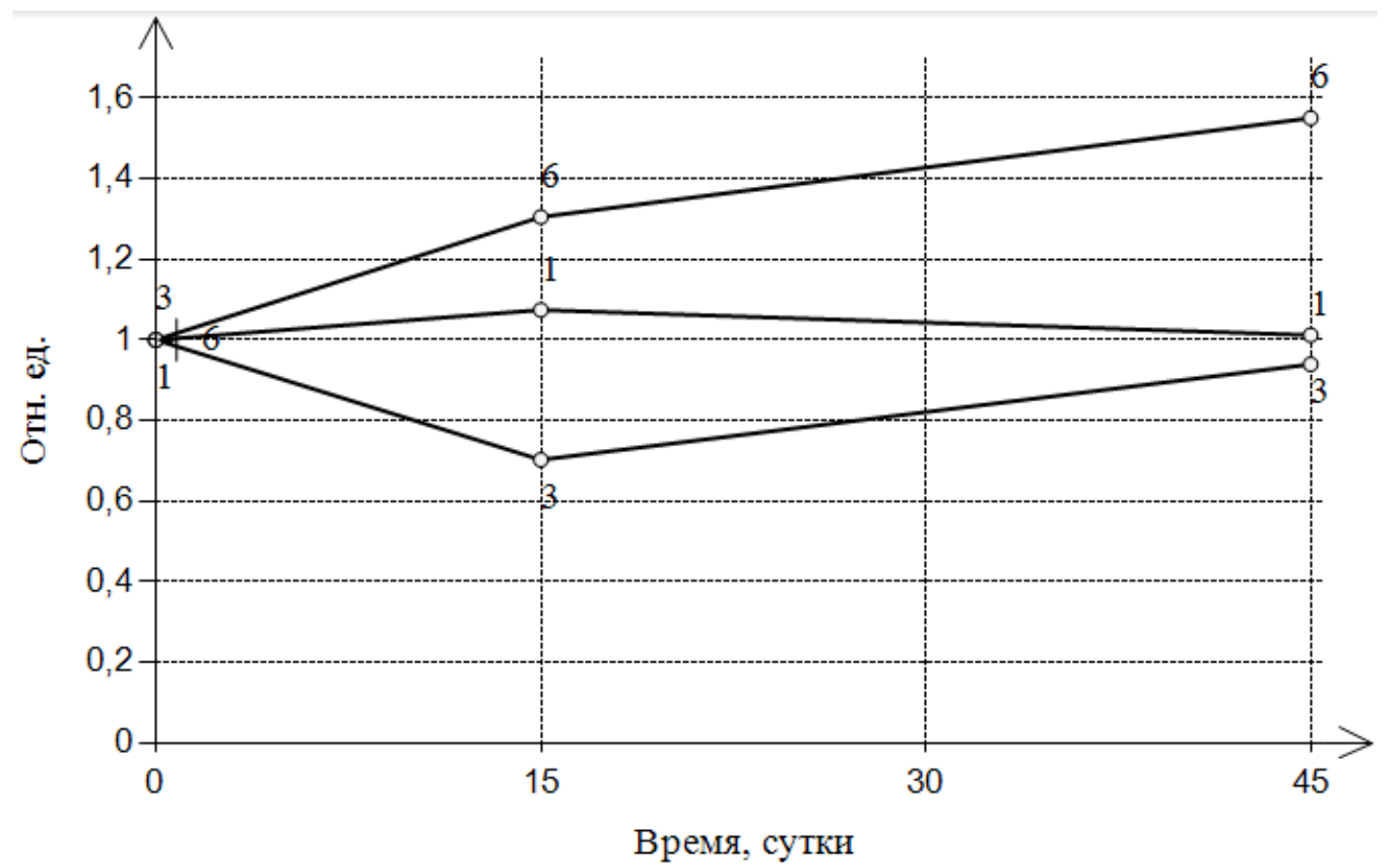

Рисунок 4. Изменение коэффициента твердости композита в зависимости от времени воздействия среды для составов 1, 3 и 6.

Таблица 5. Результаты экспонирования композитов при повышенной влажности и переменной положительной температуре $\left(22-60{ }^{\circ} \mathrm{C}\right)$ составов $1,4,5,6$.

\begin{tabular}{|c|c|c|c|c|c|c|c|c|c|c|c|c|}
\hline \multirow[t]{2}{*}{$\begin{array}{c}\text { Длительность } \\
\text { экспонирова- } \\
\text { ния, сутки }\end{array}$} & \multicolumn{4}{|c|}{$\begin{array}{c}\text { Показатели } \\
\text { твердости МПа, } \\
\text { для составов }\end{array}$} & \multicolumn{4}{|c|}{$\begin{array}{c}\text { Относительные } \\
\text { показатели твердости } \\
\text { для составов }\end{array}$} & \multicolumn{4}{|c|}{$\begin{array}{c}\text { Площадь } \\
\text { многоугольника, } \\
\text { для составов }\end{array}$} \\
\hline & 1 & 4 & 5 & 6 & 1 & 4 & 5 & 6 & 1 & 4 & 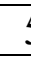 & 6 \\
\hline 0 & $\begin{array}{l}\frac{1}{0} \\
\frac{0}{o}\end{array}$ & $\begin{array}{l}\text { ลू } \\
\stackrel{0}{+} \\
\text { ஸे }\end{array}$ & $\begin{array}{l}0 \\
\infty \\
0 \\
\frac{1}{5} \\
5\end{array}$ & $\begin{array}{l}\hat{n} \\
\hat{\infty} \\
0 \\
\dot{y}\end{array}$ & \begin{tabular}{l}
8 \\
8 \\
8 \\
\hdashline
\end{tabular} & $\begin{array}{l}8 \\
8 \\
8 \\
-1\end{array}$ & $\begin{array}{l}8 \\
8 \\
8 \\
8\end{array}$ & $\begin{array}{l}8 \\
8 \\
8 \\
8\end{array}$ & \multirow{3}{*}{$\begin{array}{l}8 \\
0 \\
n \\
\infty \\
b \\
y\end{array}$} & \multirow{3}{*}{ 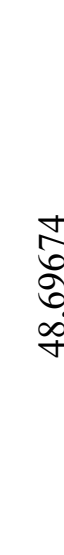 } & \multirow{3}{*}{ 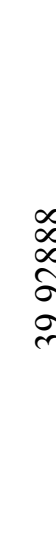 } & \multirow{3}{*}{ 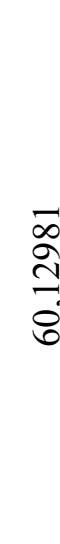 } \\
\hline 15 & $\begin{array}{l}\infty \\
\infty \\
\infty \\
\infty \\
\infty \\
\infty\end{array}$ & $\frac{a}{2}$ & 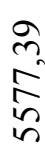 & $\frac{a}{n}$ & 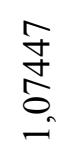 & $\begin{array}{l}\infty \\
\infty \\
\infty \\
\infty \\
\infty \\
0\end{array}$ & $\begin{array}{l}\text { N } \\
\text { Nิ } \\
\tilde{\sigma}\end{array}$ & 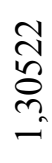 & & & & \\
\hline 45 & $\begin{array}{l}n \\
\infty \\
\infty \\
\stackrel{+}{+}\end{array}$ & 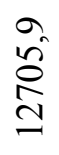 & 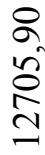 & तु & $\begin{array}{l}\stackrel{\circ}{\Xi} \\
\stackrel{0}{0}\end{array}$ & $\begin{array}{l}\infty \\
\infty \\
\infty \\
\stackrel{\infty}{\infty} \\
\stackrel{+}{+}\end{array}$ & $\begin{array}{l}\text { ñ } \\
\text { ñ } \\
\text { n్ }\end{array}$ & $\begin{array}{l}\text { N } \\
\infty \\
i n \\
n \\
n\end{array}$ & & & & \\
\hline
\end{tabular}

Сравнение между собой рассмотренных составов показывает достаточно высокие физико-механические свойства у материалов нового поколения, включающих в своем составе одновременно с двумя фракциями кварцевого наполнителя гиперпластификатор, каменную муку и микрокремнезем. 
Исследование поведения цементных композитов в условиях повышенной влажности и переменных положительных температур

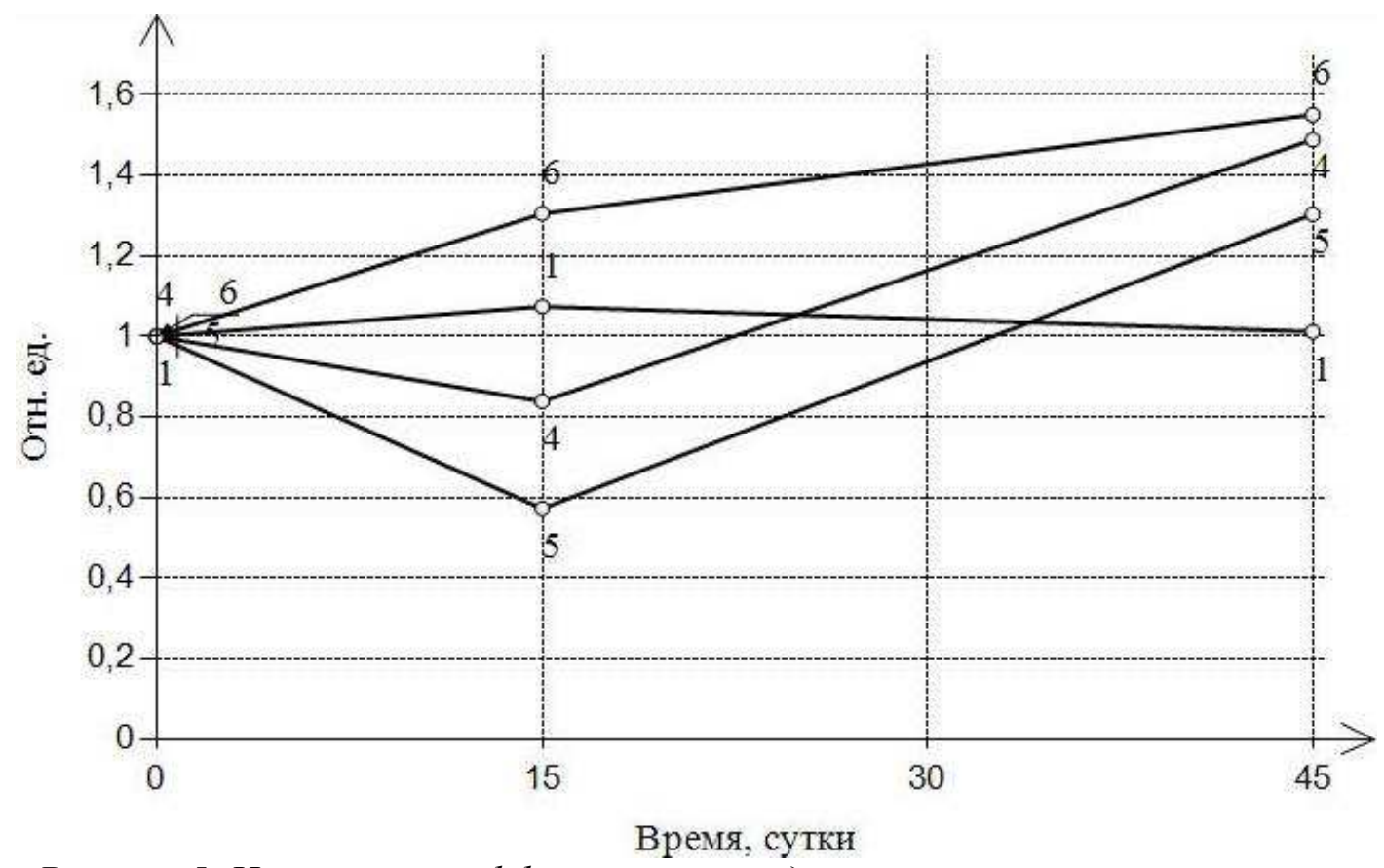

Рисунок 5. Изменение коэффициента твердости композита в зависимости от времени воздействия среды для составов 1, 4, 5 и 6.

Таблича 6. Результаты экспонирования композитов при повышенной влажности и переменной положительной температуре $\left(22-60{ }^{\circ} \mathrm{C}\right)$ составов $1,5,7,8$.

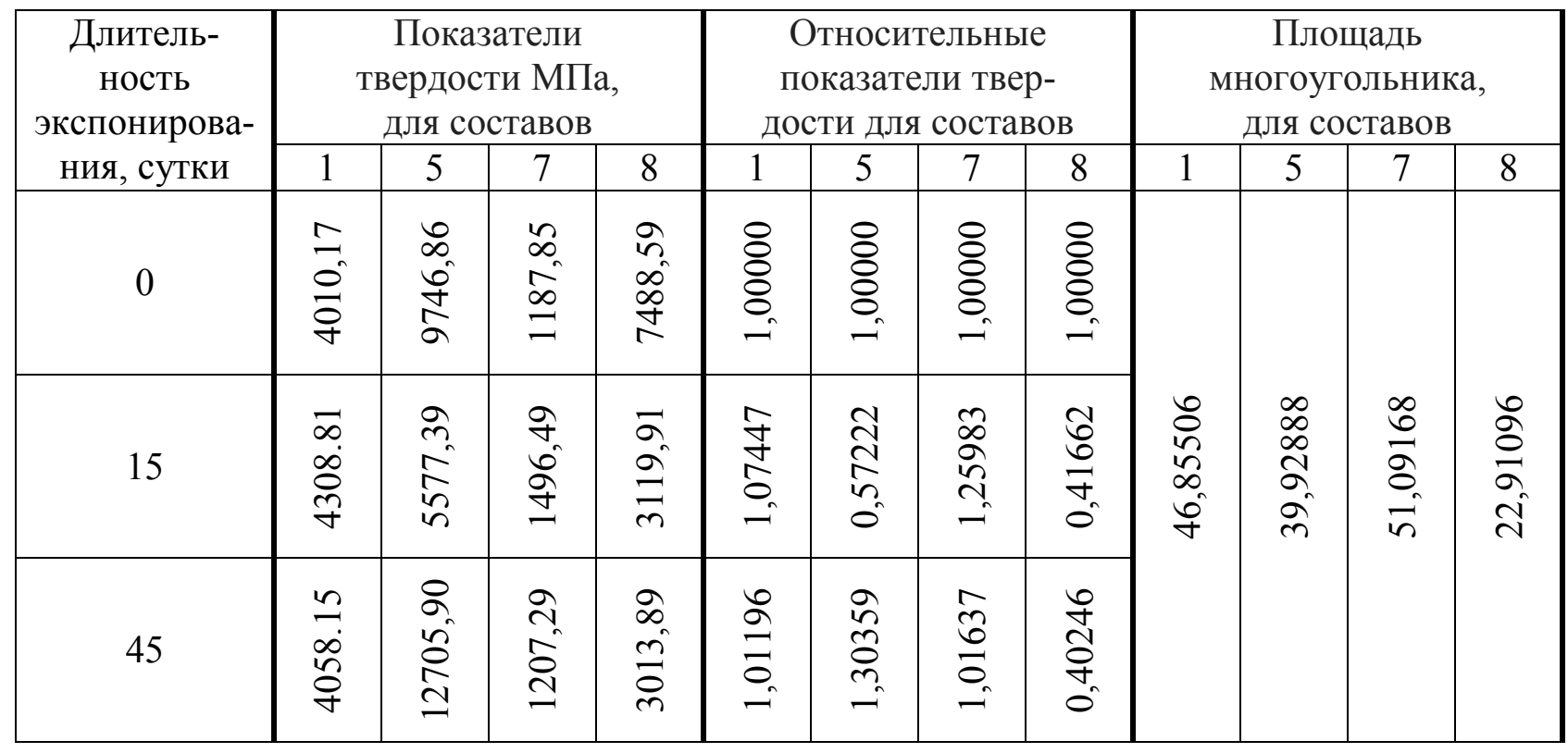

Однако, как и у композита состава 3, имеющего также высокую начальную твердость, в первые дни выдержки наблюдается снижение твердости с последующим ее повышением. Рассмотрим составы $1,5,7,8$. Состав 7 - песчаный бетон переходного поколения с ГП
Melflux. Состав 8 - песчаный бетон переходного поколения с ГП «Хидетал 9ү». Результаты расчетов приведены в таблице 6. Диаграмма с изменениями коэффициентов твердости композитов от времени их выдерживания для составов 1, 5, 7, 8 приведена на рис. 6 . 


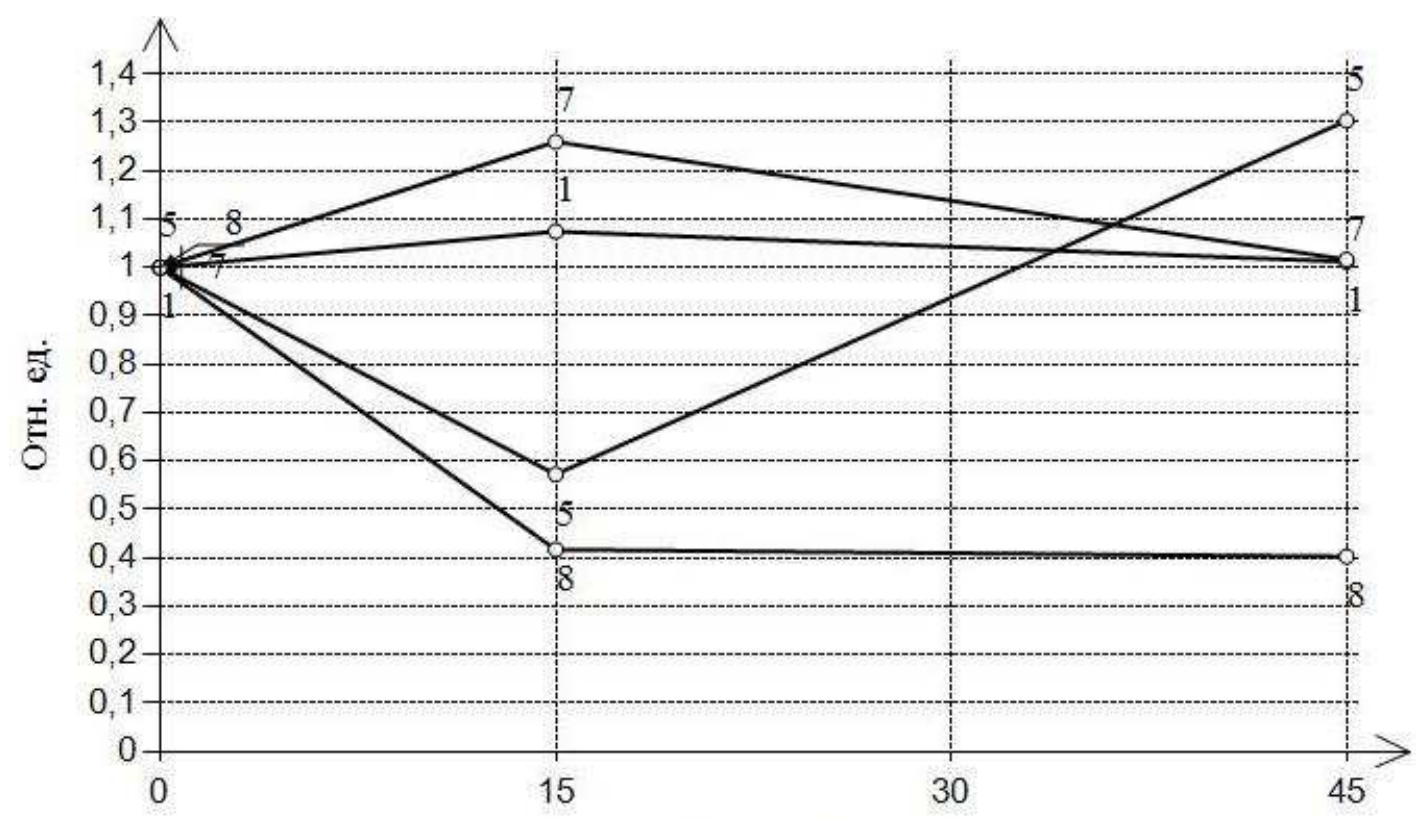

Время, сутки

Рисунок 6. Изменение коэффициента твердости композита в зависимости от времени воздействия среды для составов 1, 5, 7, 8.

Результаты испытаний свидетельствуют о том, что повышенные значения влажности и температуры приводят к более значительным изменениям свойств цементных композитов с добавкой ГП «Хидетал», чем у материалов с ГП «Melflux». В тоже время начальная твердость значительно выше у материалов с гиперпластификатором «Хидетал». Очевидно, что композит с высокой твердостью в начальное время испытания в среде с повышенной влажностью и переменными положительными температурами $\left(23-60{ }^{\circ} \mathrm{C}\right)$ теряет ее на $60 \%$. В то же время материал, имеющий показатель твердости в несколько раз меньше, не уменьшает его в течение всего периода испытания в этой же среде.

Рассмотрим составы 1 и М3. Состав М3 - это цементный камень на активированной по режиму Э+М (3-3) воде затворения. Шифр Э+М (3-3) означает, что вода затворения обработана электрическим током с плотностью $\mathrm{J}_{\max }=22 \mathrm{~A} / \mathrm{M}^{2}$ в камере электрохимической активации и электромагнитным полем c $\mathrm{H}_{\max }=75 \mathrm{\kappa H} /$ м в камере электромагнитной активации. Результаты расчетов приведены в таблице 7. Диаграмма с изменениями коэффициентов твердости от времени для составов 1 и М3 приведена на рис. 7.

Из таблицы 7 и рис. 7 видно, что активная вода затворения значительно не повлияла на стойкость цементного камня. Она меньше у цементного камня на активированной воде. Об этом свидетельствует и площади многоугольников. Для такого композита наблюдается в начальное время выдержки в среде снижение поверхностной твердости на $40 \%$.

Рассмотрим составы 1 и Т3. Состав Т3 - это биостойкий композит с добавкой «Teflex Универсальный». Результаты расчетов приведены в таблице 8. Диаграмма с изменениями коэффициентов твердости композитов от времени их выдерживания в среде для составов 1 и Т3 приведена на рис. 8 .

Испытания образцов, приготовленных из составов с биоцидной добавкой и без нее, показали уменьшение твердости образцов с добавкой. При этом из результатов также видно, что изменения твердости у образцов обоих составов при выдержке в среде имеют примерно одинаковый характер. 
Исследование поведения цементных композитов в условиях повышенной влажности и переменных положительных температур

Таблица 7. Результаты экспонирования композитов при повышенной влажности и переменной положительной температуре $\left(22-60{ }^{\circ} \mathrm{C}\right)$ составов $1, \mathrm{M} 3$.

\begin{tabular}{|c|c|c|c|c|c|c|}
\hline $\begin{array}{c}\text { Длительность } \\
\text { экспонирования, } \\
\text { сутки }\end{array}$ & \multicolumn{2}{|c|}{$\begin{array}{c}\text { Показатели } \\
\text { твердости МПа, } \\
\text { для составов }\end{array}$} & \multicolumn{2}{|c|}{$\begin{array}{c}\text { Относительные } \\
\text { показатели } \\
\text { твердости } \\
\text { для составов }\end{array}$} & \multicolumn{2}{|c|}{$\begin{array}{c}\text { Площадь } \\
\text { многоугольника, } \\
\text { для составов }\end{array}$} \\
\cline { 1 - 5 } & 1 & M3 & 1 & M3 & 1 & M3 \\
\hline 0 & 4010,17 & 5168,04 & 1,00000 & 1,00000 & 46,85506 & 39,23126 \\
\hline 15 & 4308,81 & 3081,12 & 1,07447 & 0,59619 & & \\
\hline 45 & 4058,15 & 6310,88 & 1,01196 & 1,22114 & & \\
\hline
\end{tabular}

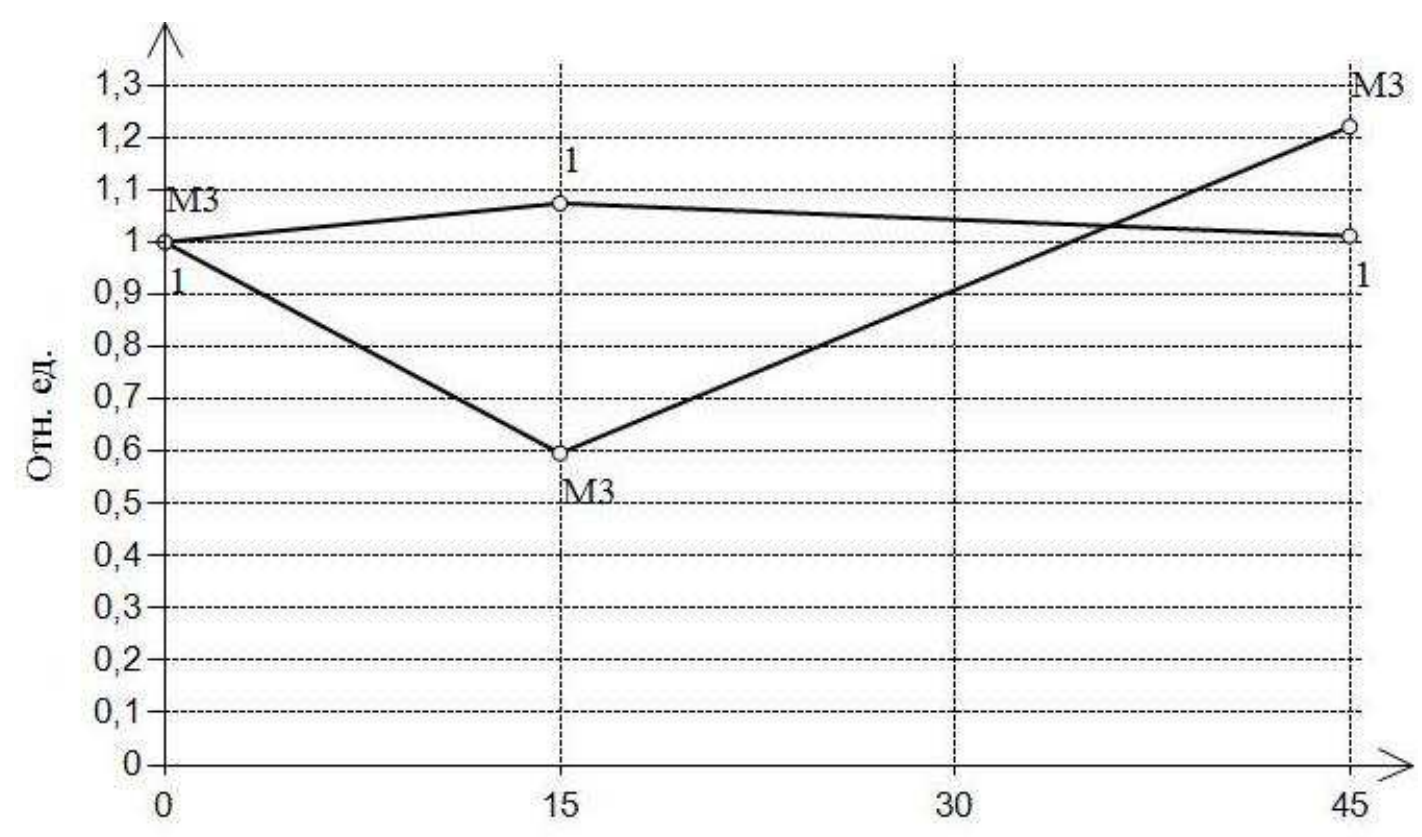

Время, суткн

Рисунок 7. Изменение коэффициента твердости композита в зависимости от времени воздействия среды для составов 1 и МЗ

Таблица 8. Результаты экспонирования композитов при повышенной влажности и переменной положительной температуре $\left(22-60{ }^{\circ} \mathrm{C}\right)$ составов 1, Т3.

\begin{tabular}{|c|c|c|c|c|c|c|}
\hline $\begin{array}{c}\text { Длительность } \\
\text { экспонирования, } \\
\text { сутки }\end{array}$ & \multicolumn{2}{|c|}{$\begin{array}{c}\text { Показатели } \\
\text { твердости МПа, } \\
\text { для составов }\end{array}$} & $\begin{array}{c}\text { Относительные } \\
\text { показатели твердости } \\
\text { для составов }\end{array}$ & \multicolumn{2}{|c|}{$\begin{array}{c}\text { Площадь } \\
\text { многоугольника, } \\
\text { для составов }\end{array}$} \\
\cline { 1 - 5 } & 1 & T3 & 1 & Т3 & 1 & Т3 \\
\hline 0 & 4010,17 & 1174,46 & 1,00000 & 1,00000 & 46,85506 & 52,21704 \\
\hline 15 & 4308,81 & 1518,65 & 1,07447 & 1,29306 & & \\
\hline 45 & 4058,15 & 1223,25 & 1,01196 & 1,04154 & & \\
\hline
\end{tabular}

Первоначальные свойства материалов при воздействии среды практически не изменились. Уменьшение начальной твердости не наблюдается. Однако, как и в других случаях, материал, имеющий начальную твердость меньше, в первое время воздействия среды больше уплотняется.

Таким образом, в рассматриваемой статье установлено изменение свойств на поверхности образцов на основе пластифицированных 


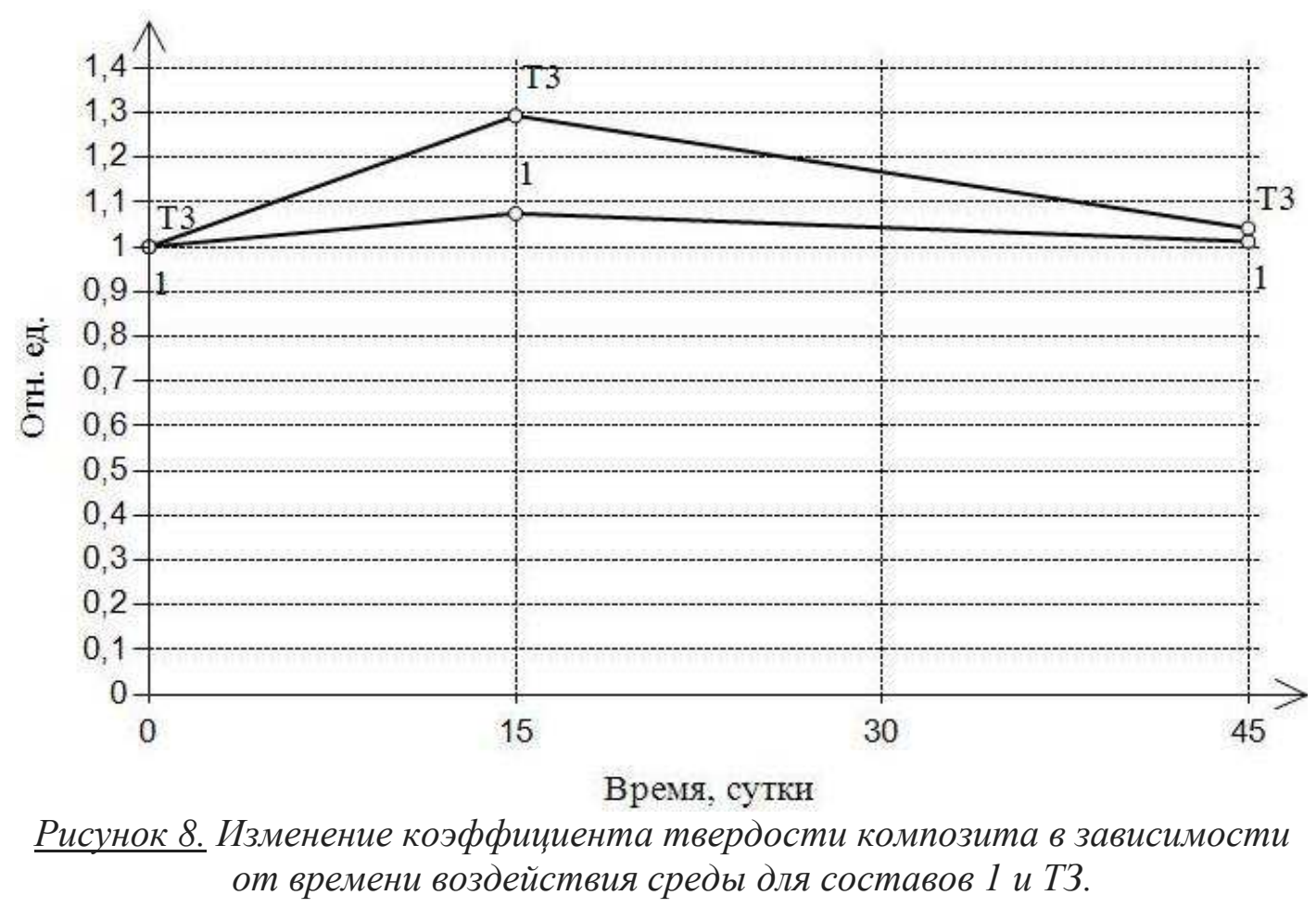

и биоцидных цементных композиций с различными наполнителями. Устойчивость (стойкость) структуры композитов предложено оценивать по величине площади многоугольника, полученного в результате кусочно-линейной интерполяции точек экспонирования.

Кроме того экспериментально установлено, что композиты, имеющие начальные показатели твердости от 1174,46 МПа до 4089,57 МПа по мере выдержки в среде с повышенной влажностью и переменными положительными температурами их не снижают, а наоборот, наблюдается даже повышение, в основном в начальное время испытания. А более твердые композиты, с показателями твердости от 5168,04 МПа до 9746,86 МПа, имеют тенденцию в начальное время воздействия среды уменьшать свою поверхностную твердость, затем ее увеличивать или сохранять, как например песчаный композит с ГП Хидетал 9у. Закономерностям изменения поверхностной твердости цементных композитов можно найти объяснение из рассмотрения особенностей их отвердевания, приведенных в научной и учебной литературе $[19,20,21$,
22]. Приведем некоторые положения при отвердевании цементных композитов:

- темп упрочнения цементного композита в позднем возрасте уменьшается при повышении его прочности [20];

- $\quad$ величина недобора прочности композита увеличивается при более высоких значениях водоцементного отношения (В/Ц) смеси [20];

- карбонизация цементных композитов становится незначительной при относительной влажности близкой к $100 \%$, потому что в микропорах происходит конденсация водяного пара и их диффузионная проницаемость снижается на несколько порядков $[19,21]$;

- карбонизация развивается тем быстрее, чем выше температура и менее плотен бетон, поскольку в этом случае возрастает количество пор, не заполненных конденсатом [19, 21];

- колебания температуры в оптимальных пределах при повышенной относите! шей влажности могут дополнительно способствовать образованию зародышей материала с последующим его упрочнением [22]. 
Исследование поведения цементных композитов в условиях повышенной влажности и переменных положительных температур

Принимая во внимание результаты исследования, приведенные в табл. 1, согласно которым твердость больше у композитов с более высокой прочностью на сжатие, можно предположить, что повышение и сохранение твердости менее твердых материалов в начальное время действия среды связано с их большей потенциальной возможностью упрочняться, а соответственно повышать поверхностное отвердевание.

Роль карбонизации композитов в упрочнении незначительна, она поверхностна и все же больше для менее твердых композитов, поскольку они имеют поры больших размеров, которые не заполняются конденсатом, что способствует уменьшению сопротивления карбонизации.

Уменьшение твердости более плотных композитов в начальное время выдержки в среде с повышенной влажностью и переменными положительными температурами можно объяснить их микропористой структурой, в которой конденсируется влага, приводящая к временному снижению твердости из-за поверхностного увлажнения. Однако с появлением новых центров кристаллизации из-за колебания положительных температур появляется возможность упрочнения композитов, а соответственно повышения их твердости [22].

Роль составляющих композита, в частности добавок, сказывается в основном с их влиянием на интегральную и дифференциальную пористость материала, на его прочность и твердость. Это влияние требует детального изучения, поскольку при общей тенденции повышения твердости с повышением прочности мы не можем говорить о том, что между характеристиками этих свойств наблюдается прямая зависимость (см. таблицу 1).

\section{СПИСОК ЛИТЕРАТУРЫ}

1. Меркулов Д.А., Коротаев С.А., Ерофеев В.T. Оптимизация гранулометрического состава кварценаполненных полиэфирных композитов. // БСТ : Бюллетень строительной техники, 2017, № 5(993), с. 31-33.

2. Ерофеев В.Т., Смирнов И.В., Меркулов Д.А., Мышкин А.В., Старцев В.О., Молоков М.В., Блазнов А.Н., Журковский M.E. Теплостойкость полимерных композитов на основе различных связующих. // БСТ : Бюллетень строительной техники, 2017, №5(993), с. 34-36.

3. Ерофеев В.Т., Федорцов А.П., Карпушин С.Н., Воронов П.В., Родин А.И., Болдина И.В. Коррозионная стойкость цементных композитов, изготовленных на основе биоцидных портландцементов с активной минеральной добавкой. // Фундаментальные исследования, 2017, № 4-2, c. 247-256.

4. Ерофеев В.Т., Смирнов В.Ф., Лазарев А.В., Богатов А.Д., Казначеев С.В., Родин А.И., Смирнова О.Н., Смирнов И.В. Биологическая и климатическая стойкость полимерных композитов. // Academia. Архитектура и строительство, 2017, №1, с. 112-119.

5. Ерофеев В.Т., Афонин В.В., Черушова Н.В., Зоткина М.М., Митина Е.А., Зоткин В.Б., Ерофеева И.В. Методы и алгоритмы оценки качества поверхности строительных изделий и конструкций // Фундаментальные исследования, 2016, №4-1, c. 33-40.

6. Ерофеев В.Т., Смирнов И.В., Воронов П.В., Афонин В.В., Каблов Е.Н., Старцев О.В., Старцев В.О., Медведев И.М. Исследование стойкости полимерных покрытий в условиях воздействия климатических факторов Черноморского побережья. // Фундаментальные исследования, 2016, №11-5, c. 911-923.

7. Смирнов И.В., Воронов П.В., Светлов Д.А., Афонин В.В., Качалов А.Н. Климатическая стойкость эпоксидных композитов, наполненных портландцементом. // Сборник статей международной научно-технической конференции «Композиционные строительные материалы. Теория и практика», 2016, с. 79-81. 
8. Смирнов И.В., Воронов П.В., Светлов Д.А., Афонин В.В., Харитонов Ян.А. Климатическая стойкость эпоксидных композитов в зависимости от содержания отвердителя. // Сборник статей международной научно-технической конференции «Композиционные строительные материалы. Теория и практика», 2016, с. 8284.

9. Смирнов И.В., Воронов П.В., Афонин В.В., Светлов Д.А., Харитонов Ян.А. Климатическая стойкость эпоксидных композитов в зависимости от содержания разжижителя - бутилового спирта. // Сборник статей международной научнотехнической конференции «Композиционные строительные материалы. Теория и практика», 2016, с. 85-88.

10. Ерофеев В.Т., Родин А.И., Калашников В.И., Ерофеева И.В., Смирнов В.Ф. Биостойкость декоративных цементных композитов. // Вестник Волжского регионального отделения Российской академии архитектуры и строительных наук, 2016, №19, с. 304-308.

11. Ерофеев В.Т., Богатов А.Д., Федорцов А.П., Пронькин С.П. Исследование механизмов повреждения битумных композитов в условиях воздействия биологических агрессивных сред. // Фундаментальные исследования, 2015, №2-13, с. 27872800.

12. Зоткина М.М., Зоткин В.Б., Емельянов Д.В., Захарова Е.А., Черушова Н.В., Ерофеева И.В., Афонин В.В. Изменение декоративных свойств пигментированных цементных композитов в результате воздействия биологических агрессивных сред. // Сборник трудов XIV Международной научно-технической конференции «Актуальные вопросы архитектуры и строительства», 2015, с. 221-224.

13. Turusov R.A., Kuperman A.M., Yakhontova E.R. Regular composite. // Polymer Science, Series D, 2014, Vol. 7, Iss. 1, pp. 913.
14. Бобрышев А.Н., Ерофеев В.Т., Козомазов В.Н. Физика и синергетика дисперсно-неупорядоченных конденсированных композитных систем. - СПб.: Наука, 2012. - 476 c.

15. Сутягин В.М., Ляпков А.А. Физико-химические методы исследования полимеров. - Томск : Изд-во Томского политехнического университета, 2010. - 140 с.

16. Турусов Р.А., Егоров В.И., Счастливцев И.В., Баранов А.О., Науменко В.Ю. Результаты испытаний образцов трахеи и вида соединяющих швов. // Механика композиционных материалов и конструкций, 2009, Том 15, №2, с. 289-305.

17. Ерофеев В.Т., Митина Е.А., Матвиевский А.А., Осипов А.К., Емельянов Д.В., Юдин П.В. Композиционные строительные материалы на активированной воде затворения. // Строительные материалы, 2007, №11, с. 56-58.

18. Фудзии Т., Дзако М. Механика разрушения композиционных материалов. - М:. Мир, 1982. - 232 с.

19. Алексеев С.Н., Розенталь Н.К. Коррозионная стойкость железобетонных конструкций в агрессивной промышленной среде. - М. : Стройиздат, 1976. - 205 с.

20. Баженов Ю. М. Технология бетона. - М.: Высшая школа, 1987. - 415 с.

21. Новичков П.И. Теоретические основы конструирования железобетонных элементов с учетом сопротивления физическим и химическим воздействиям. - СПб. : Наука, 2011. - 216 с.

22. Федорцов А.П. Физико-химическое сопротивление строительных композитов и способы его повышения. - Саранск: Издательство Мордовского университета, $2015-464$ c.

\section{REFERENCES}

1. Merkulov D.A., Korotaev S.A., Erofeev V.T. Optimizacija granulometricheskogo sostava kvarcenapolnennyh polijefirnyh 
Исследование поведения цементных композитов в условиях повышенной влажности и переменных положительных температур

kompozitov [Optimization of the granulometric composition of quarten-filled polyester composites]. // BST Bulleten stroitelnoy tekhniki, 2017, Number 5(993), pp. 31-33.

2. Erofeev V.T., Smirnov I.V., Merkulov D.A., Mishkin A.V., Startsev V.O., Molokov M.V., Blaznov A.N., Zhurkovsky M.E. Teplostojkost' polimernyh kompozitov na osnove razlichnyh svjazujushhih [Heat resistance of polymer composites based on various binders]. // BST Bulleten stroitelnoy tekhniki, 2017, Number 5(993), pp. 34-36.

3. Erofeev V.T, Fedortsov A.P., Karpushin S.N., Voronov P.V., Rodin A.I., Boldina I.V. Korrozionnaja stojkost' cementnyh kompozitov, izgotovlennyh na osnove biocidnyh portlandcementov s aktiv-noj mineral'noj dobavkoj [Corrosion resistance of cement composites made on the basis of biocidal Portland cement with an active mineral additive]. // Fundamentalnie Issledovaniya, 2017, Vol. 4-2, pp. 247-256.

4. Erofeev V.T., Smirnov V.F., Lazarev A.V., Bogatov A.D., Kaznacheev S.V., Rodin A.I., Smirnova O.N., Smirnov I.V. Biologicheskaja i klimaticheskaja stojkost' polimernyh kompozitov [Biological and climatic stability of polymer composites]. // Academia. Arkhitektura i stroitelstvo, 2017, Number 1, pp. 112-119.

5. Erofeev V.T., Afonin V.V., Cherushova N.V., Zotkina M.M., Mitina E.A., Zotkin V.B., Erofeeva I.V. Metody i algoritmy ocenki kachestva poverhnosti stroitel'nyh izdelij i konstrukcij [Methods and algorithms for assessing the surface quality of building products and structures]. // Fundamentalnie Issledovaniya, 2016, Vol. 4-1, pp. 33-40.

6. Erofeev V.T., Smirnov V.F., Voronov P.V., Afonin V.V., Kablov E.N., Startsev O.V., Startsev V.O., Medvedev I.M. Issledovanie stojkosti polimernyh pokrytij $\mathrm{V}$ uslovijah vozdejstvija klimaticheskih faktorov Chernomorskogo poberezh'ja [Investigation of the durability of polymer coatings under the influence of climatic factors of the Black Sea coast]. // Fundamentalnie Issledovaniya, 2016, Vol. 11-5, pp. 911-923.

7. Smirnov I.V., Voronov P.V., Svetlov D.A., Afonin V.V., Kachalov A.N. Klimaticheskaja stojkost' jepoksidnyh kompozitov, napolnennyh portlandcementom [The climatic stability of epoxy composites filled with Portland cement]. // Proceedings of the International scientific and technical conference "Kompozicionnye stroitel'nye materialy. Teorija i praktika", 2016, pp. 79-81.

8. Smirnov I.V., Voronov P.V., Svetlov D.A., Afonin V.V., Kharitonov Y.A. Klimaticheskaja stojkost' jepoksidnyh kompozitov $\mathrm{V}$ zavisimosti ot soderzhanija otverditelja [The climatic stability of epoxy composites depending on the content of the hardener]. // Proceedings of the International scientific and technical conference "Kompozicionnye stroitel'nye materialy. Teorija i praktika", 2016, pp. 82-84.

9. Smirnov I.V., Voronov P.V., Afonin V.V., Svetlov D.A., Kharitonov Y.A. Klimaticheskaja stojkost' jepoksidnyh kompozitov $\mathrm{V}$ zavisimosti ot soderzha-nija razzhizhitelja butilovogo spirta [The climatic stability of epoxy composites, depending on the content of the diluent - butyl alcohol]. // Proceedings of the International scientific and technical conference "Kompozicionnye stroitel'nye materialy. Teorija i praktika", 2016, pp. 8588.

10. Erofeev V.T., Rodin A.I., Kalashnikov V.I., Erofeeva I.V., Smirnov V.F. Biostojkost' dekorativnyh cementnyh kompozitov [Biostability of decorative cement composites]. // Vestnik Volzhskogo regional'nogo otdelenijah Rossijskoj akademii arhitektury i stroitel'nyh nauk, 2016, Number 19, pp. 304-309.

11. Erofeev V.T., Bogatov A.D., Fedortsov A.P., Pronkin S.P. Issledovanie mehanizmov povrezhdenija bitumnyh kompozitov $\mathrm{V}$ uslovijah vozdejstvija biologicheskih agressivnyh sred [Investigation of the mechanisms of damaging bituminous composites 
under the conditions of the action of biological corrosive media]. Fundamentalnie Issledovaniya, 2015, Vol. 2-13, pp. 2787-2800.

12. Zotkina M.M., Zotkin V.B., Emelyanov D.V., Zakharova E.A., Cherushova N.V., Erofeeva I.V., Afonin V.V. Izmenenie dekorativnyh svojstv pigmentirovannyh cementnyh kompozitov v rezul'tate vozdejstvija biologicheskih agressivnyh sred [Change in the decorative properties of pigmented cement composites as a result of exposure to biological corrosive media]. Proceeding of the 14th International Scientific and Technical Conference "Aktual'nye voprosy arhitektury i stroitel'stva", 2015, pp. 221-224.

13. Turusov R.A., Kuperman A.M., Yakhontova E.R. Regular composite. // Polymer Science, Series D, 2014, Vol. 7, Iss. 1, pp. 913.

14. Bobrishev A.N., Erofeev V.T., Kozomazov V.N. Fizika i sinergetika dispersno-neuporjadochennyh kondensirovannyh kompozitnyh system [Physics and Synergetics of Disperse-Disordered Condensed Composite Systems]. Saint-Petersburg, 2012, 476 pages.

15. Sutyagin V.M., Lyapkov A.A. Fizikohimicheskie metody issledovanija polimerov [Physico-chemical methods for the study of polymers]. Tomsk, Izdatelstvo Tomskogo politekhnicheskogo universiteta, 2010, 140 pages.

16. Turusov R.A., Egorov V.I., Schastlivtsev I.V., Baranov A.O., Naumenko V.Yu. Rezul'taty ispytanij obrazcov trahei $\mathrm{i}$ vida soedinjajushhih shvov [The results of tests of tracheal specimens and the kind of joints]. // Mehanika kompozicionnyh materialov i konstrukcij, 2009, Vol. 15, Iss. 2, pp. 289305.

17. Erofeev V.T., Mitina E.A., Matvievsky A.A., Osipov A.K., Emelyamov D.V., Yudin P.V. Kompozicionnye stroitel'nye materialy na aktivirovannoj vode zatvorenija [Composite building materials on activated mixing water]. // Stroutelniye materiali, 2007, Number 11, pp. 56-58.

18. Fudzin T., Dzako M. Mehanika razrushenija kompozicionnyh materialov [Mechanics of fracture of composite materials]. Moscow, Mir, 1982, 232 pages.

19. Alekseev S.N., Rozental N.K. Korrozionnaja stojkost' zhelezobetonnyh konstrukcij v agressivnoj promyshlennoj srede [Corrosion resistance of reinforced concrete structures in an aggressive industrial environment]. Moscow, Stroyizdat, 1976, 205 pages.

20. Bazhenov Yu.M. Tehnologija betona [Technology of concrete]. Moscow, Visshaya shkola, 1987, 415 pages.

21. Novichkov P.I. Teoreticheskie osnovy konstruirovanija zhelezobetonnyh jelementov $\mathrm{s}$ uchetom soprotivlenija fizicheskim i himicheskim vozdejstvijam [Theoretical bases of designing reinforced concrete elements with regard to resistance to physical and chemical influences]. Saint-Petersburg, 2011, 216 pages.

22. Fedortsov A.P. Fiziko-himicheskoe soprotivlenie stroitel'nyh kompozitov i sposoby ego povyshenija [Physico-chemical resistance of building composites and ways to improve it]. Saransk, Izdatelstvo Mordovskogo universiteta, 2015, 464 pages.

Ерофеева Ирина Владимировна, Мордовский государственный университет им. Н.П. Огарёва; 430005, Российская Федерация, Республика Мордовия, г. Саранск, ул. Большевистская, д. 68; тел. +7 (8342) 47-29-13; e-mail: vvafonin53@yandex.ru.

Афонин Виктор Васильевич, доцент, кандидат технических наук, доцент кафедры автоматизированных систем обработки информации и управления, Мордовский государственный университет имени Н. П. Огарёва; 430005, Россия, Республика Мордовия, г. Саранск, ул. Большевистская, д. 68;

тел. +7 (8342) 29-06-02; e-mail: vvafonin53@yandex.ru.

Федорцов В.А., Мордовский государственный университет им. Н.П. Огарёва; 430005, Российская Федерация, Республика Мордовия, г. Саранск, ул. Большевистская, д. 68; тел. +7 (8342) 47-29-13; e-mail: vvafonin53@yandex.ru. 
Исследование поведения цементных композитов в условиях повышенной влажности и переменных положительных температур

Емельянов Денис Владимирович, Мордовский государственный университет им. Н.П. Огарёва; 430005, Российская Федерация, Республика Мордовия, г. Саранск, ул. Большевистская, д. 68;

тел. +7 (8342) 47-29-13; e-mail: vvafonin53@yandex.ru.

Подживотов Николай Юрьевич, кандидат технических наук, лаборатория №30, Всероссийский научно-исследовательский институт авиационных материалов ГНЦ РФ; 105005, Россия, Москва, ул. Радио, д. 17;

тел.: +7 (499) 261-86-77, +7 (499) 267-21-09;

факс: +7 (499) 267-86-09; e-mail: admin@viam.ru.

Зоткина Марина Михайловна, кандидат технических наук; кафедра строительных материалов и технологий, Мордовский государственный университет им. Н.П. Огарёва; 430005, Российская Федерация, Республика Мордовия, г. Саранск, ул. Большевистская, д. 68; тел. 7 (8342) 47-29-13; e-mail: vvafonin53@yandex.ru.

Irina V. Erofeeva, National Research Ogarev Mordovia State University; 68 Bolshevistskaya Str., Saransk 430005, Republic of Mordovia, Russia; phone +7 (8342) 47-29-13; e-mail: vvafonin53@yandex.ru.

Victor V. Afonin, Associate Professor, Ph.D., Associate Professor of Department of automated information processing and management systems, National Research Ogarev Mordovia State University; 68 Bolshevistskaya Str., Saransk 430005, Republic of Mordovia, Russia;

phone +7 (8342) 29-06-02;

e-mail: vvafonin53@yandex.ru.

Vladislav A. Fedortsov, National Research Ogarev Mordovia State University; 68 Bolshevistskaya Str., Saransk 430005, Republic of Mordovia, Russia;

phone +7 (8342) 47-29-13;

e-mail: vvafonin53@yandex.ru.

Denis V. Emelyanov, National Research Ogarev Mordovia State University; 68 Bolshevistskaya Str., Saransk 430005, Republic of Mordovia, Russia; phone +7 (8342) 47-29-13; e-mail: vvafonin53@yandex.ru.

Nikolay Yu. Podzhivotov, Ph.D, Laboratory 30, All-Russian Scientific Research Institte of Aviation Materials GNC RF; 17, Ulitsa Radio, Moscow, 105055, Russia;

phones: +7 (499) 261-86-77, +7 (499) 267-21-09; fax: +7 (499) 267-86-09; e-mail: admin@viam.ru.

Marina M. Zotkina, Ph.D, Department of Construction Materials and Technologies, National Research Ogarev Mordovia State University; 68 Bolshevistskaya Str., Saransk 430005, Republic of Mordovia, Russia;

phone +7 (8342) 47-29-13;

e-mail: vvafonin53@yandex.ru. 